\title{
REPRESENTASI SANTRI DALAM TRAILER \\ FILM THE SANTRI
}

\author{
Anita Sartika
}

Universitas Islam Negeri Syarif Hidayatullah, Jakarta, Indonesia anitasartika22@gmail.com

\begin{tabular}{ll}
\hline & Abstrak \\
\hline Article History & PBNU is working a film called The \\
Received : 12-12-2020 & Santri which is expected to be media of \\
Revised : 14-12-2020 & da'wah. However, not long after the \\
Accepted : 15-12-2020 & trailer was released, contra opinion \\
\hline Keywords: & appeared among the fellow muslims. \\
Film, & Those who deny consider The Santri \\
Nahdlatul Ulama, & does not represent the ideal of santri. In \\
The Santri, & fact, PBNU has been known as an \\
Santri, & Islamic organization with the highest \\
Representation. & number of pesantren. Therefore, the \\
& representation of santri on this trailer \\
& should be the best representation. Thus, \\
& this article aims to analysis how santri \\
& is represented. The researcher uses \\
& semiotic method which revealed the \\
& meaning of signs by Charles Sanders \\
& Peirce. The analysis shows there are \\
& several scenes that enable the \\
& representation of santri to get the pros \\
& and cons because they related with \\
& legisign-type objects, which are related \\
& to Islamic law. Although there are \\
scenes that represent students well, \\
such as having high dreams and \\
diligently worship.
\end{tabular}

\section{Pendahuluan}

Dakwah merupakan kewajiban setiap muslim sebagaimana perintah Allah swt. dalam Al-Quran, di antaranya terdapat dalam Q.s. An-Nahl: 125, Q.s. Al-Hajj: 67, Q.s. Al-Qhashash: 87 dan Q.s. Aliimran: 104. Berdakwah artinya menyeru manusia kepada Allah, menyuruhkepada yang ma'ruf dan mencegah dari yang munkar. 
Dalam Q.s. An-Nahl: 125 misalnya, Allah swt. dengan jelas memerintahkan hamba-Nya untuk berdakwah. "Serulah manusia kepada jalan Tuhanmu dengan hikmah dan pengajaran yang baik, dan berdebatlah dengan mereka dengan cara yang baik. Sesungguhnya Tuhanmu, Dia-lah yang lebih mengetahui siapa saja yang tersesat dari jalan-Nya, dan Dia mengetetahui siapa yang mendapat petunjuk."

Dalam prosesnya, terdapat tantangan dalam berdakwah, salah satunya adalah adanyaperbedaan pemahaman di kalangan umat Islam itu sendiri.Perbedaan pemahaman dalam hal furuiyah sebenarnya merupakan satu hal yang wajar selama kita dapat menjaga persatuan dan ukhuwah Islamiyah. Namun, tidak jarang perbedaan pemahaman tampaknya kurang bisa diterima dengan baik oleh masyarakat, sehingga memicu beragam perselisihan dan perdebatan.

Terkait dengan hal ini, salah satu yang menarik perhatian peneliti adalah hadirnyatrailer film The Santri yang digagas oleh Pengurus Besar Nahdlatul Ulama (PBNU). Pada bulan September 2019, PBNU melalui kanal youtube $N U$ Channel merilis trailer film berjudul Official Trailer Film The Santri. Melaluifilm tersebut, NU berharapdapat mendakwahkan Islam yang santun dan menjadikan Indonesia sebagai kiblat peradaban. PBNU juga menyatakan bahwa film ini diluncurkan sebagai media dakwah dalam konteks pendidikan, budaya, dan akhlak(Tribunnews, 2019).

Namun, tidak lama setelah traileryang sudah ditonton $3,754,146$ views dirilis (jumlah views pada tanggal 5 Juni 2020), munculbanyak pro dan kontradari sesama umat Islam. Hal ini dapat dilihat dari reaksi yang diberikan netizen di kolom komentar video tersebut. Tidak sedikit netizen yang menyayangkan hadirnya trailer film The Santri. Selain itu, menjadi menarik ketika NU Channeltidak menampilkan jumlah like dan dislike, berbeda dengan videolainnya di kanal milik NU ini. Beberapa organisasi Islam juga turut menyatakan penolakan secara langsung, misalnya Forum Umat Islam (FUI), Forum Santri Indonesia (FSI), dan Dewan Pimpinan Pusat Front Pembela Islam (DPP FPI).

Adapun respon kontra tersebut didasarkan pada hal yang sama, yaitu karena trailer filmThe Santri dianggap tidak merepresentasikan santri dan kehidupan pesantren yang ideal. Forum Umat Islam (FUI) mengecam adegan santri masuk gereja dan dua orang santri bukan mahrom berdua-duaan karena dianggap bukan budaya yang hidup di 
lingkungan pesantren(CNN, 2019). Forum Santri Indonesia (FSI) menolak trailer film The Santri karena menganggap trailer tersebut tidak mencerminkan akhlak dan tradisi santri yang sebenarnya. Bahkan, Dewan Pimpinan Pusat Front Pembela Islam (DPP FPI) meminta kepada para santri dan jamaahnya agar tidak menonton The Santri lantaran menilai film tersebut tidak sesuai dengan syariat Islam serta tidak mengandung tradisi pesantren ahlussunah wal jamaah(CNN, 2019).

Artinya, penolakan dan kecaman terhadap trailer film ini tidak terlepas dari representasi santri yang ditampilkan. Dalam kajian media studies, Branston dan Stanfford menyatakan bahwa media bukanlah cermin dari realitas kehidupan dan tidak menampilkan dunia sesungguhnya secara langsung. Sebaliknya, apa yang ditampilkan di media adalah hasil konstruksi atau sebuah representasi (Branston and Stanfford 2010). Hal inilah yang memungkinkan representasi yang dihadirkan hanya diambil dari kelompok tertentu dan tidak menampilkan kelompok lainnya.Dalam trailer film The Santri, PBNU adalah organisasi Islam yang berada dibalik produksi film tersebut, karenanya memiliki pengaruh dalam menentukan representasi yang ditampilkan.

Menariknya, PBNUsebagai penggagas trailer film The Santri merupakan organisasi massa Islam dengan jumlah pesantren terbanyak di Indonesia. Organisasi ini dikenal basis keutamaannya adalah kalangan pesantren dan NU dipastikan tidak pernah ada tanpa pesantren(Nurrohmat, 2019).NU lahir dipelopori oleh kyai pesantren, sehingga sangat beralasan untuk mengatakan bahwa NU dan pesantren tidak bisa dipisahkan. Pesantren dianggap menjadi basis gerakan NU sejak masa penjajahan hingga saat ini(Marom, 2012: 24).Bahkan Abdurrahman Wahid memberikan gambaran menarik mengenai hubungan NU dan pesantren, yaitu NU adalah pesantren yang tertulis luas dan pesantren adalah NU yang tertulis kecil (Abdurrahman, 2017).

Keistimewaan tersebut menjadikan NU memiliki kesempatan untuk merepresentasikan santri dan pesantren dengan baik lewat karya mereka. Sehingga, representasi santri yang dihadirkan dalam trailer film The Santriseharusnya adalah representasi terbaik yang dihadirkan oleh NU. Akan tetapi, respon kontra yang berarti adanya penolakan atau ketidaksetujuan, menjadikan representasi santri dalam 
trailermenarik untuk diteliti. Oleh karena itu, penelitian ini bermaksud mengetahui bagaimana santri direpresentasikan dalam trailer film The Santri. Penelitian ini menggunakan analisis semiotika model Charles Sanders Peirce.

Penelitian terkait trailer film The Santri sudah pernah dilakukan sebelumnya, namun berbeda dengan penelitian yang peneliti lakukan. Misalnya, penelitian Lailatul Maghfiroh (2020) yang melakukan analisis framing terhadap pemberitaan VOA Islam dan Tribunnews dalam memberitakan kontroversi film The Santri.Arianne (2020) juga pernah melakukan penelitian terkait trailer film ini dengan melakukan analisis semiotika Roland Barthes terhadap scene dalam trailer yang mengundang beragam kontroversi. Namun, penelitian terdahulu tersebut tidak secara spesifik menganalisis mengenai bagaimana representasi santri dalam trailer film The Santri. Sehingga, penelitian ini berbeda dari penelitian yang sudah ada sebelumnya.

\section{Metodologi Penelitian}

Penelitian ini berparadigma subjektif dengan pendekatan kualitatif, dan metode deskriptif. Paradigma subjektif adalah paradigma yang menganggap bahwa pengetahuan tidak mempunyai sifat objektif, melainkan bersifat interpretatif dan makna dapat dinegosiasikan(Nurhadi, 2017: 27). Adapun objek dalam penelitian ini adalah trailer film The Santri berupa potongan gambar dari adegan atau scene. Sebagai alat analisisnya, peneliti menggunakan model analisis semiotika Charles Sanders Peirce.

\section{Pembahasan}

\section{Representasi Media}

Dalam studi media, representasi merupakan salah satu kajian yang populer dan penting untuk dilakukan. Istilah representasi biasa digunakan untuk menggambarkan ekspresi hubungan antara teks media dengan realitas yang ada (Dewi, 2013: 64). Menurut Stuart Hall, representasi adalah memproduksi makna lewat bahasa. Hall juga mengutip pengertian representasi dari The Shorter Oxford English Dictionary, yakni merepresentasikan sesuatu berarti mendeskripsikannya, memunculkan gambaran atau imajinasi dalam benak kita, menempatkan kemiripan dari objek dalam pikiran atau indera kita. Merepresentasikan sesuatu dapat juga didefinisikan 
sebagai menyimbolkan, mencontohkan, menempatkan sesuatu, atau menggantikan sesuatu (Hall, 1997: 16).

Benshof dan Griffin mengartikan representasi sebagaiproses menyajikan gambar tentang sesuatu untuk mengkomunikasian sebuah ide atau menceritakan sebuah cerita (Bensoff, 2004: 350). Definisi lain diberikan oleh Burton yang menganggap representasi menyangkut pembuatan makna. Dalam hubungannya dengan media, media massa dipercaya selalu membentuk makna dari realitas di sekeliling khalayak dan cara untuk memahami realitas tersebut. Apa yang ditampilkan di media merupakan sebuah representasi dari kelompok tertentu dan membentuk makna mengenai kelompok tersebut (Ditha Prasanti, 2016).

Representasi media menjadi hal yang menarik karena menurut Branston dan Stanford, apa yang ditampilkan di media bukanlah cerminan langsung dari realitas dunia, melainkan sebuah konstruksi atau representasi (Branston dan Stafford, 2010: 107). Hal ini sesuai dengan pernyataan Hall dan Van Dijk bahwa karakter yang ditampilkan di media seringkali tidak mewakili kejadian nyata atau disajikan dengan keliru (misrepresentation) atau menggambarkan stereotip kelompok minoritas (Ahmed dan Matthes, 2017: 219).

Media juga dianggap tidak menghadirkan 'dunia' secara keseluruhan melainkan apa yang ditampilkan di media hanya bagian tertentu saja. Sehingga, menimbulkan pertanyaan tentang siapa yang berkuasa untuk menentukan bagian mana yang direpresentasikan dan tidak direpresentasikan. Pertanyaan lainnya adalah jika sesuatu hanya direpresentasikan dengan sudut pandang tertentu saja bahkan terbatas, maka bagaimana hal ini terkait dengan pemahaman publik dan bagaimana publik diperlakukan dari hasil representasi ini (Branston dan Stafford, 2010).

Menurut Branston dan Stanford, pemilik media berkuasa menentukan representasi apa yang akan ditampilkan. Karenanya, apa yang tampak di media adalah hasil konstruksi atau presentasi ulang. Media tidak menampilkan cerminan langsung dari realitas atau dalam istilah Branston dan Stanford media bukanlah "clear window on the real"(Branston dan Stafford, 2010: 107).

Dalam kaitannya dengan representasi santri dalam tayangan trailer film The Santri, santri dalam trailer film tersebut merupakan hasil kontruksi atau presentasi ulang dari tim produksi di balik trailer 
tersebut. Ketika muncul pro dan kontra terhadap representasi santri yang ditampilkan, artinya ada kelompok yang merasa tidak terwakilkan dalam representasi tersebut atau berbeda pemahaman dalam memaknai bagaimana santri seharusnya.

\section{Trailer Film}

Trailer adalah iklan suatu film atau program televisi yang berisi cuplikan adegan-adegan menarik atau paling menegangkan untuk menarik minat calon pemirsa. Trailer biasanya berdurasi antara 30-180 detik (Soebazary, 2010: 264). Karena tujuan dari trailer adalah menarik perhatian penonton, maka adegan yang dipilih untuk dijadikan trailer adalah bagian yang menarik, lucu, atau bagian yang penting dari film tersebut (Wikipedia, 2019). Selain itu, sebagai iklan, sebagaimana menurut Kernan, trailer bertujuan menunjukkan kelebihan suatu film, sehingga dapat menjadi "film we want to see" bagipenonton(Horvath dan Gyenge, 2018: 94). Trailer berdampak signifikan terhadap keinginan kaum muda untuk menonton suatu film.

Menurut Horvath dan Gyenge ((Horvath dan Gyenge, 2018), terdapat enam tipe trailer film, yaitu:

\section{Teaser Trailers}

Trailer jenis ini biasanya mencoba untuk menggoda penonton tanpa mengungkapkan banyak detail tentang film. Teaser Trailers hanya menampilkan potongan cepat dari sebuah film ke dalam 30-90 detik, terutama yang mewakili suasana hati keseluruhan film. Bahkan, trailer ini dapat dirilis sebelum syuting keseluruhan film selesai.

\section{Standar Trailer}

Standar trailer biasanya berdurasi 2-3 menit, yang isinyamemperkenalkan karakter atau menjelaskan narasi utama plot.

\section{Creative Trailer}

Trailer jenis ini tidak menggunakan cuplikan apa pun dari film itu sendiri, melainkan dibuat secara independen untuk mempromosikan film tersebut. Kadang-kadang sutradara menembak plot mereka sendiri yang lebih kecil yang entah bagaimana terhubung ke film untuk keperluan iklan. Namun, 
trailer jenis ini tidak umum digunakan karena biaya produksinya yang lebih tinggi.

Featurettes

Featurettes biasanya berdurasi lebih panjang (5-10 menit), terdiri dari dua subkategori utama, "pembuatan" dan "di belakang layar". Perbedaan utama antara keduanya adalah bahwa yang pertama lebih berfokus pada peristiwa sebelum pengambilan gambar (seperti bagaimana ide untuk film sampai pada tahap praproduksi untuk mengeluarkan skenario sepanjang jalan ke awal pengambilan gambar), sedangkan yang kedua memberikan sekilas pekerjaan on-set.

Clip Trailer

Clip Trailer dibuat dengan mengambil adegan pendek yang menarik dari film dan menggunakannya untuk mempromosikan film tersebut tanpa diedit atau diperbaiki. TV Spots

Trailer jenis ini mirip dengan trailer standar (sering muncul hanya sebagai versi singkat), berdurasi 30-60 detik sama dengan trailer teaser, yang diiklankan lewat TV sebagai bagian dari dorongan terakhir dari kampanye pemasaran yang mengarahkan penonton ke bioskop. Menurut Gray (2008), trailer film dapat memberikan kesempatan bagi penonton untuk membayangkan, dan mengekspresikan harapan, serta menciptakan kecemasan mereka sendiri. Semua ini dapat menyebabkan film ditafsirkan sebagian, atau dihargai sebelum film tersebut benar-benar dirilis (Horvath dan Gyenge, 2018: 96). Sehingga, trailer film menjadi sangat penting sebagai alat penarik perhatian penonton.

\section{Santri}

Istilah santri diyakini berasal dari bahasa Sansekerta "shastri" yang berarti orang yang belajar kalimat suci dan indah(Octavia 2014), atau orang yang tahu kitab-kitab suci (Berg dalam Zaini Mochtarom, 1988: 6).Berg meyakini kata "shastri"diturunkan dari kata "shastra"yang berarti kitab suci, karya keagamaan atau ilmiah.Kata "shastri" kemudian mengalami perubahan bentuk, sebagaimana menurut Siradj, para wali songo mengadopsi istilah "shastri" tersebut menjadi santri. Sirajd mendefinisikan "shastri" atau "santri" sebagai 
orang yang belajar kalimat suci dan indah, yakni kitab suci Al-Quran dan hadist. Al-Quran dan hadist tersebut kemudian diajarkan, dipahami, dan dimanifestasikan dalam kehidupan sehari-hari.(Siradj dalam Octavia, 2014: ix). Dalam KBBI, kata santri didefiniskan sebagai orang yang mendalami agama Islam, orang yang beribadah secara sungguh-sungguh, serta orang yang saleh.

Clifford Geertz, seorang tokoh yang memperkenalkan konsep abangan, santri dan priyayi, menerapkan istilah santri pada kebudayaan para muslimin yang memegang peraturan dengan keras dan biasanya tinggal bersama di kota dalam perkampungan dekat sebuah masjid (Zaini Mochtarom, 1988: 2). Sedangkan menurut Kern, istilah santri dalam artinya yang asli dan sempit mengacu kepada para siswa di sekolah agama yang biasa disebut pesantren (Zaini Mochtarom, 1988: 7). Terkait dengan pesantren, menurut Asmuki, santri sebagai murid yang belajar di pondok pesantren terbagi menjadi dua kategori. Pertama, Santri yang belajar di pesantren tetapi tidak tinggal di pesantren atau biasa disebut santri kalong.Kedua, santri yang belajar dan menetap di pesantren atau biasa disebut santri muqim (Abu Yasid dkk., 2018: 198).

Dalam hubungannya dengan pesantren, istilah pesantren merupakan turunan kata dari "santri", dengan dibubuhi awalan pedan akhiran -an. Pesantrenadalah pusat pendidikan Islam tradisional atau sebuah pondok untuk para siswa muslim sebagai model sekolah agama Islam di Jawa (Zaini Mochtarom, 1988: 6). Dengan kata lain, santri dan pesantren tidak dapat dipisahkan, mereka memiliki hubungan yang sangat erat.

\section{Analisis Semiotika Model Charles Sanders Peirce}

Semiotika merupakan studi ilmu atau metode analisis yang biasa digunakan untuk mengungkap makna dari apa yang ditampilkan di media. Apa yang ditampilkan di media seperti skenario, gambar, teks dan adegan di film menjadi sesuatu yang dapat dimaknai dengan mengkaji tanda-tanda yang ada di dalamnya. Istilah semiotik berasal dari kata Yunani semeion yang berarti tanda, atau dari kata semeiotikos yang artinya teori tanda (Dadan Rusmana, 2014: 19).Dalam Kamus Besar Bahasa Indonesia (KBBI), semiotika diartikan sebagai ilmu teori tentang lambang dan tanda (dalam bahasa, lalu lintas, kode morse, dan sebagainya). Sedangkan tanda itu sendiri didefinisikan sebagai suatu yang atas dasar konvensi sosial 
yang terbangun sebelumnya dapat dianggap mewakili sesuatu yang lain (Wibowo, 2013: 18).

Analisis semiotika merupakan salah satuusaha yang dapat dilakukan untuk mengungkapkan sesuatu yang perlu dipertanyakan lebih lanjut ketika membaca teks, narasi atau wacana tertentu. Analisis semiotika bersifat paradigmatik karena berupaya menemukan makna dari hal-hal yang tersembunyi di balik sebuah teks. Namun, tidak hanya teks, analisis semiotika juga biasa digunakan untuk mengungkap tanda-tanda dibalik film.

Dalam analisis semiotika, dikenal dua tokoh founding father yang banyak berperan, yakni Ferdinand De Saussure dari dataran Eropa, dan Charles Sandeirs Peirce dari dataran Amerika. Dalam penelitian ini, peneliti menggunakan analisis semiotika model Charles Sandeirs Peirce yang teorinya seringkali disebut sebagai 'grand theory' dalam semiotika. Hal ini karena gagasan Peirce bersifat menyeluruh, memuat deskripsi struktural dari sistem penandaan (Wibowo, 2013:17).

Menurut Peirce, semiotik adalah studi tentang tanda dan segala yang berhubungan dengannya, yaitu cara berfungsi (sintaksis semiotic), hubungan dengan tanda-tanda lain (semantic semiotic), serta pengirim dan penerimanya oleh mereka yang menggunakannya (pragmatik semiotik) (Dadan Rusmana, 2014: 168). Semiotika adalah suatu hubungan antara tanda, objek, dan makna.

Analisis semiotika model Charles Sanders Peirce ini tentu dapat digunakan untuk menganalisis 'makna' yang terdapat dalam Film. Menurut Van Zoest, film adalah bidang kajian yang relevan bagi analisis semiotik. Hal ini karena film dibangun dengan tandatanda. Film menggunakan tanda-tanda ikonis, yakni tanda-tanda yang menggambarkan sesuatu.(Alex Sobur 2009) Dalam model Peirce, tanda-tanda yang dihadirkan di dalam sebuah film dapat dianalisis dengan menggunakan triangle meaning.

Menurut Peirce, prinsip mendasar dari sifat tanda adalah sifat representatif dan interpretatif. Sifat representatif tanda berarti tanda adalahperwakilan dari sesuatu yang lain (something that represents something else). Sedangkan sifat interpretatif artinya setiap orang memiliki peluang untuk menginterpretasikan tanda. Pemikiran Peirce dapat dipahami dengan segitiga makna berikut ini: 


\section{Gambar 1. Segitiga Makna Charles Sanders Peirce}

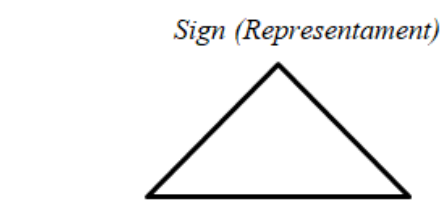

Interpretant

Object

Menurut Peirce, tanda dibentuk oleh hubungan segitiga antara sign, interpretant dan object. Dalam pandangan Peirce, tanda (sign) berhubungan dengan objek $(\mathrm{O})$ yang dirujuknya, hubungan tersebut membuahkan interpretant (I)(Wibowo, 2013:167). Ketiga hal ini dapat dianalisis dengan tiga jalur logika, yakni hubungan antara representament dan jenis representament, hubungan antara object dan jenis representament, serta hubungan antara interpretant dan jenis representament. Dadan Rusmana( Rusmana, 2014) menjelaskannya secara detail sebagai berikut:

1. Hubungan Representament ( $\mathrm{R}$ ) dengan jenis Representament:

a. Qualisign:representament yang bertalian dengan kualitas atau warna.

b. Sinsign: representament yang bertalian dengan fakta real.

c. Legisign: representament yang bertalian dengan kaidah hukum.

2. Hubungan Object $(\mathrm{O})$ dan jenis Representament:

a. Ikon

Ikon adalah tanda yang mengandung kemiripan 'rupa' sehingga mudah dikenali oleh pemakainya. Di dalam ikon ini terdapat hubungan representament dan objek yang memiliki keserupaan atau "tiruan tak serupa" dengan bentuk objek. Contohnya, patung Soekarno adalah ikon dari Soekarno yang sebenarnya.

b. Indeks

Indeks adalah tanda yang memiliki keterkaitan fenomenal atau eksistensial di antara representament dan objeknya. Hubungan representament dan objek terjadi karena terdapat keterkaitan atau hubungan kausal antara dasar dan objeknya. Contohnya, ketukan pintu merupakan indeks dari kehadiran seorang 'tamu' di rumah kita. 


\section{c. Simbol}

Simbol adalah jenis tanda yang bersifat arbiter dan konvensional sesuai kesepakatan atau konvensi sejumlah orang atau masyarakat. Hubungan representament dan objek yang terbentuk terjadi karena adanya konvensi. Contohnya, lampu lalu lintas dengan tiga warna, merah berarti berhenti, kuning berarti hati-hati, dan hijau berarti izin siap berjalan.

3. Hubungan Interpretant (I) dengan jenis Representament (R )

a. Rheme or seme: representament yang masih memiliki berbagai kemungkinan untuk diinterpretasi oleh interpretant.

b. Dicent or dicisign: representament yang sudah dapat dijadikan fakta real dan memiliki makna tertentu.

c. Argument:representament yang sudah dihubungkan dengan kaidah atau preposisi tertentu.

\section{Sekilas TentangTrailer Film The Santri}

Trailer film The Santri pertama kali dirilis di kanal youtube milik PBNU, NU Channel, pada bulan September 2019 lalu. Unggahan tersebut diberi judul Official Trailer FilmThe Santri dengan durasi 2 menit 44 detik. Namun, trailer filmnya hanya berdurasi 1 menit 35 detik, sisanya adalah sambutan dari Ketua Umum PBNU, Said Aqil Siradj. Dalam sambutannya, Siradj menyatakan bahwa film ini bertujuan menunjukkan Islam sebagai agama yang santun, toleran, ramah, plural, dan Islam yang berbudaya akhlakul kharimah, jauh dari Islam radikal, Islam ekstrimis, apalagi Islam teror.

Digagasnya film The Santri adalah bentuk dedikasi NU dalam rangka gerakan santri melawan radikalisme dan terorisme melalui pendekatan Islam Nusantara(Alawi, 2019) Artinya, Film The Santri dihadirkan tidak terlepas dari kepedulian NU. Selain itu, film The Santri diluncurkan sebagai media dakwah dalam konteks pendidikan, budaya dan akhlak (Tribunnews, 2019). Lewat film ini, NU ingin menunjukkan Islam yang harmonis dengan budaya, kecuali budaya yang bertentangan dengan syariat. NU berharap dapat mendakwahkan Islam yang santun, menjadikan Indonesia kiblat peradaban melalui film ini (Republika, 2019). 
Film ini nantinya akan mengangkat nilai-nilai kaum santri dan tradisi pembelajaran di pondok pesantren yang berbasis kemandirian, kesederhanaan, toleransi serta kecintaan terhadap tanah air. Dalam trailernya, film ini berkisah tentang kehidupan di sebuah pondok pesantren yang sedang mempersiapkan perayaan hari santri. Seorang guru menjanjikan bahwa enam orang santri terbaik akan diberangkatkan dan bekerja di Amerika Serikat.

Hanya saja, ketika trailer film dirilis di kanal youtube $N U$ Channel, film The Santri belum sepenuhnya digarap. Imam Pituduh, Produser Eksekutif sekaligus Sekretaris Jenderal PBNU mengungkapkan bahwa film The Santri baru mulai digarap pada hari Santridan diperkirakan baru akan selesai pada April tahun 2020 (CNN, 2019).Artinya, ketika trailer film The Santri dirilis, film ini belum sepenuhnya dibuat (Detik, 2019).

\section{Analisis Semiotika Charles Sanders Peirce Terhadap Trailer Film The Santri}

Peneliti melakukan identifikasi dan klasifikasi terhadap tanda dengan megadaptasi jenis-jenis tanda (tipologi tanda) berdasarkan hubungan antara representament dan jenis representament, objek dan jenis representament, serta interpretant dan jenis representament sebagaimana yang dikemukakan oleh Peirce. Peneliti melakukan analisis terhadap beberapa scene, termasuk potongan scene yang menuai banyak kontra di kalangan masyarakat.

Gambar 2. Analisis Berdasarkan Scene dalam Trailer FilmThe Santri pada "00.01.01-00.01.07"

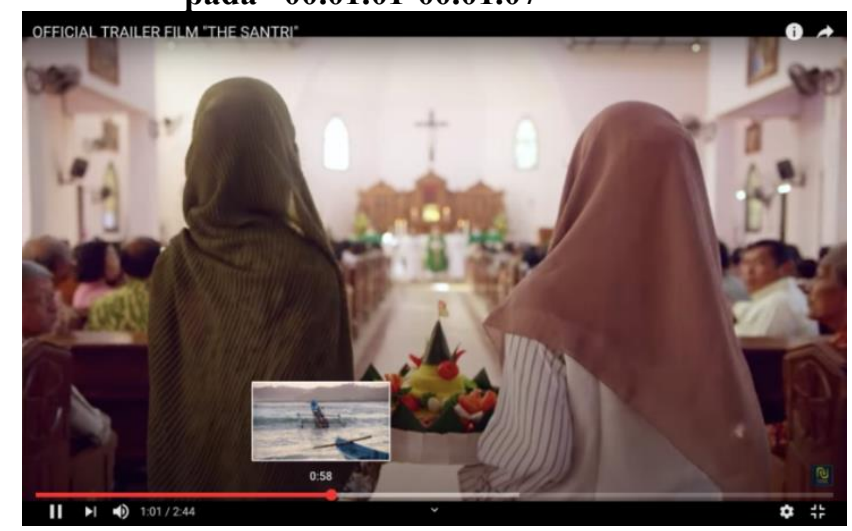

Sumber: Tangkapan Layar Trailer Film The Santri 
Peneliti menganalisis relasi triadik dalam potongan scenetrailer di atas. Pada scene tersebut, sign menunjukkan gereja dan kalimat "please accept this sign of love." Klasifikasi tanda berdasarkan sign berjenis legisgn. Adapun object dalam scene tersebut adalah dua orang santriwati membawa tumpeng ke dalam gereja. Klasifikasi berdasarkan object berjenis symbol. Sedangkan Interpretantnya menunjukkan dua orang santriwati menghadiri kegiatan agama lain di gereja. Mereka membawa tumpeng sebagai bentuk menghargai, menghormati, dan juga persaudaraan meskipun berbeda agama. Klasifikasi berdasarkan interpretant berjenis dicent.

Peneliti menafsirkan bahwa scene di atas menunjukkan The Santri ingin memperlihatkan bentuk toleransi antar agama. Dengan berhijab rapi, kedua santri ini merepresentasikan muslimah, sehingga scene ini menunjukkan bahwa TheSantri tidak mempersoalkan muslim yang menghadiri kegiatan di rumah ibadah agama lain. Representament atau sign dalam potongan scene ini berjenis legisign, yakni bertalian dengan kaidah atau aturan hukum dalam agama Islam. Object berjenis symbol, yakni menunjukkan bahwa The Santri mendukung toleransi, salah satunya dengan pemahaman bahwa tidak masalah bagi muslim untuk menghadiri kegiatan agama lain, sebagai bentuk the sign of love. Tafsiran atau interpretant yang peneliti lakukan berjenis dicent atau tanda yang dapat dijadikan fakta real dan memiliki makna tertentu.Terkait dengan hukum muslim masuk ke rumah ibadah agama lain memang banyak perbedaan pendapat di kalangan kaum muslimin, termasuk dalam hal memaknainya sebagai toleransi. 


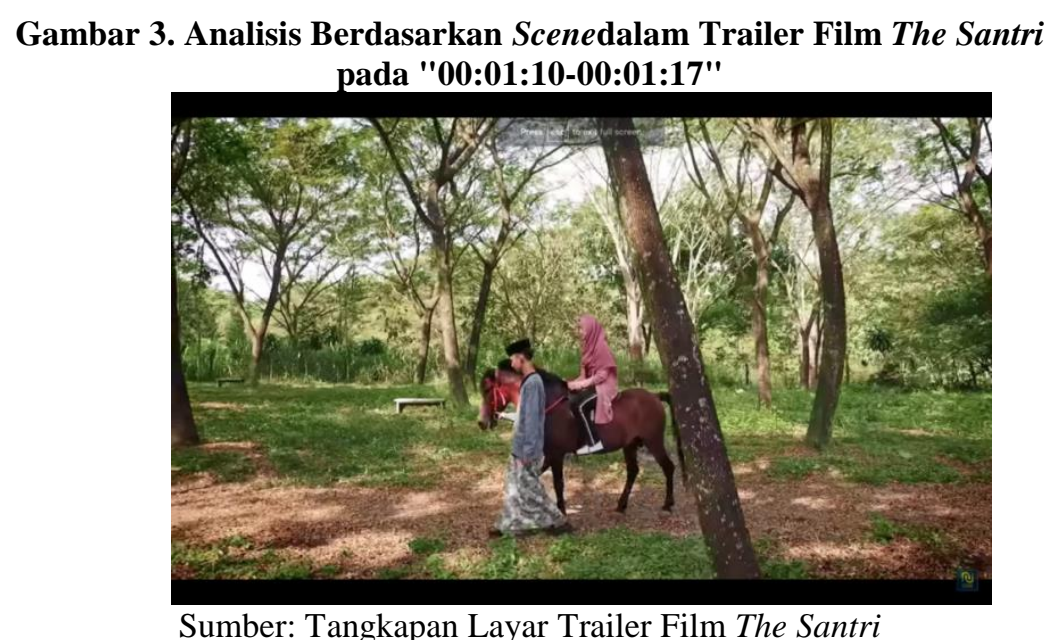

Pada potongan scene di atas, peneliti menafsirkansignberupa dua orang santri dan kalimat "kutitipkan tasbih dan tulisan ini untukmu". Klasifikasi tandanya berdasarkan sign berjenis legisign. Objectnya adalah dua orang santri sedang menyusuri taman atau hutan,santriwati menunggangi kuda, sedangkan santriwan berjalan di sebelahnya. Klasifikasi berdasarkan object berjenis indeks. Interpretantnya adalah dua orang santri ini memiliki hubungan yang cukup baik. Dalam scene ini diceritakan santriwati yang diperankan oleh Wirda Mansur akan pergi ke Amerika Serikat untuk melanjutkan pendidikan dan bekerja. Santriwan yang diperankan oleh Gus Azmi, memberikan tasbih dan sebuah bukusembarimengatakan "kutitipkan tasbih dan tulisan ini untukmu, agar kau selalu ingat Tuhan dan diriku." Klasifikasi berdasarkan interpretant berjenis dicent.

Peneliti menyimpulkan scene di atas menunjukkan adanya hubungan antara santriwan dan santriwati tersebut. Kalimat agar kau selalu ingat Tuhan dan diriku menurut peneliti bermakna keduanya menjalin hubungan yang baik sehingga salah satunya berharap untuk tidak dilupakan. Sign berjenis legisign, memungkinkan penonton menafsirkan keduanya menjalin hubungan pertemanan yang dekat. Padahal dalam dunia pesantren hal seperti ini cukup tabu untuk dilakukan, karena adanya aturan dalam hubungan antara santri lakilaki dan perempuan. 
Gambar 4. Analisis Berdasarkan Scenedalam Trailer Film The Santri pada "00:01:24-00:01:27"
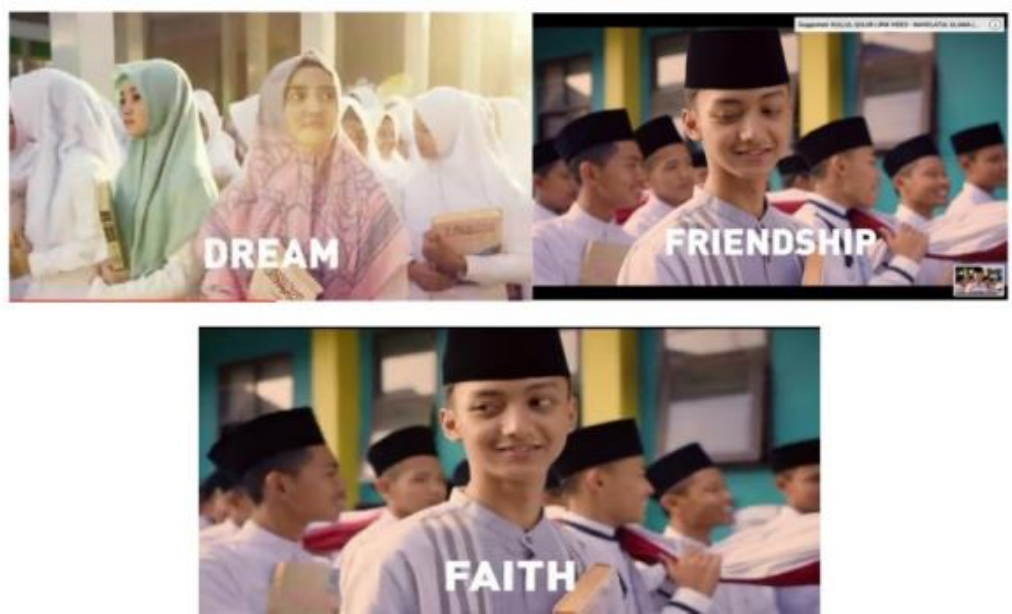

Sumber: Tangkapan Layar Trailer Film The Santri

Pada potongan scene di atas, peneliti menafsirkan sign berupa santriwan dan santriwati yang saling bersitatap dan kata dream, fight dan friendship. Klasifikasi tanda berdasarkan sign berjenis sinsign. Objeknya adalah dua orang santri saling bersitatap sembari tersenyum satu sama lain saat sedang berjalan berombongan serta adanya tulisandream, fight, dan friendship. Klasifikasi berdasarkan object berjenis symbol. Interpretantnya mengungkapkan bahwa kedua tokoh ini memang memiliki hubungan pertemanan yang dekat. Kata dream, fight dan friendship mengungkapkan kehidupan santri yang dipenuhi dengan mimpi, perjuangan, dan persahabatan. Klasifikasi berdasarkan interpretant berjenis argument.

Peneliti menyimpulkan bahwa tulisan dream, faith, dan friendship menunjukkan bahwa kehidupan pesantren dipenuhi dengan mimpi, perjuangan dan persahabatan. Namun yang menarik adalah bagaimana trailer ini merepresentasikan adegan saling berpandangan antara tokoh utama santriwati dan santriwannya. Scene ini sangat memungkinkan menuai banyak pro dan kontra, karena selama ini kehidupan pesantren dipandang sangat membatasi hubungan antara laki-laki dan perempuan.

Setidaknya 3 scene di atas yang paling banyak menuai komentar di kalangan kaum muslimin, khususnya netizen di kolom komentar NU Channel. Namun, sebagai representasi santri, scene 
lainnya peneliti rasa juga perlu untuk diteliti. Misalnya pada dua scene berikut ini.

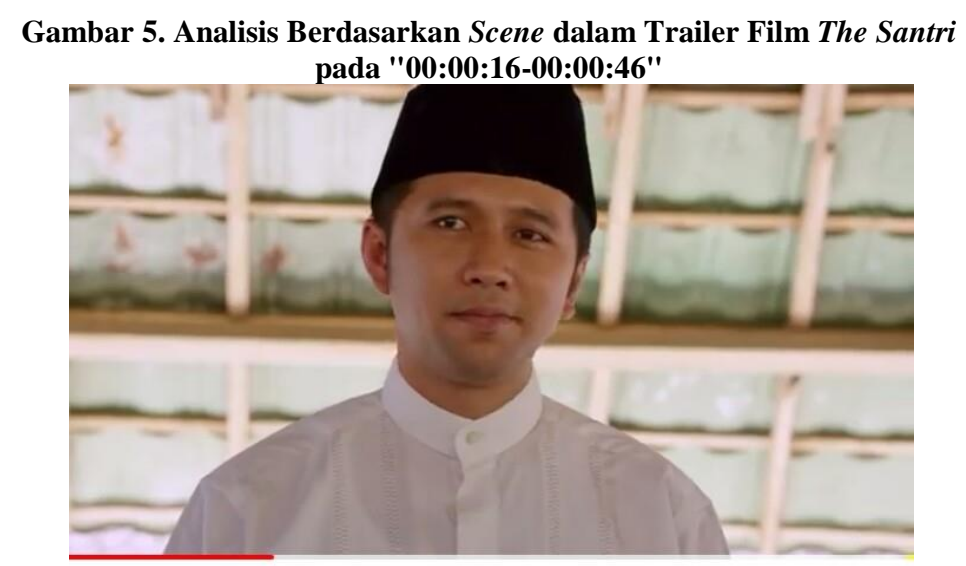

Sumber: Tangkapan Layar Trailer Film The Santri

Pada potongan scene di atas, terdapat dialog yang disampaikan oleh guru atau ustaz yang diperankan oleh Emil Dardak. Dalam dialog tersebut ustaz menyatakan "Santri adalah bagian yang tidak dapat dipisahkan dari perjalanan bangsa Indonesia. Pada hari santri ini enam yang terbaik di antara kalian akan terpilih untuk berangkat dan bekerja di Amerika Serikat. Buatlah negaramu dan agamamu bangga”. Dialog ini merupakan sign berjenis sinsign. Object berupa seorang guru yang sedang menasihati santri-santrinya untuk semangat meraih mimpi. Klasifikasi berdasarkan object berjenis ikon. Adapun interpretantnya santri adalah harapan bangsa dan agama. Karena itulah, santri diharapkan dapat berjuang meraih mimpi setinggi-tingginya. Klasifikasi berdasarkan interpretant berjenis argument.

Peneliti menafsirkan makna dari scene ini adalah sebagai representasi dari kehidupan santri yang dipenuhi impian. Sign berupa dialog "santri adalah bagian yang tidak dapat dipisahkan dari perjalanan bangsa Indonesia" merepresentasikan bagaimana di kehidupan sesungguhnya santri banyak berperan dalam membangun bangsa. Representasi ini dikuatkan kembali dengan kalimat "buatlah negaramu dan agamamu bangga." Object dalam scene ini berjenis ikon, artinya santri dengan impian yang tinggi merupakan representasi dari kehidupan santri di dunia nyata. 


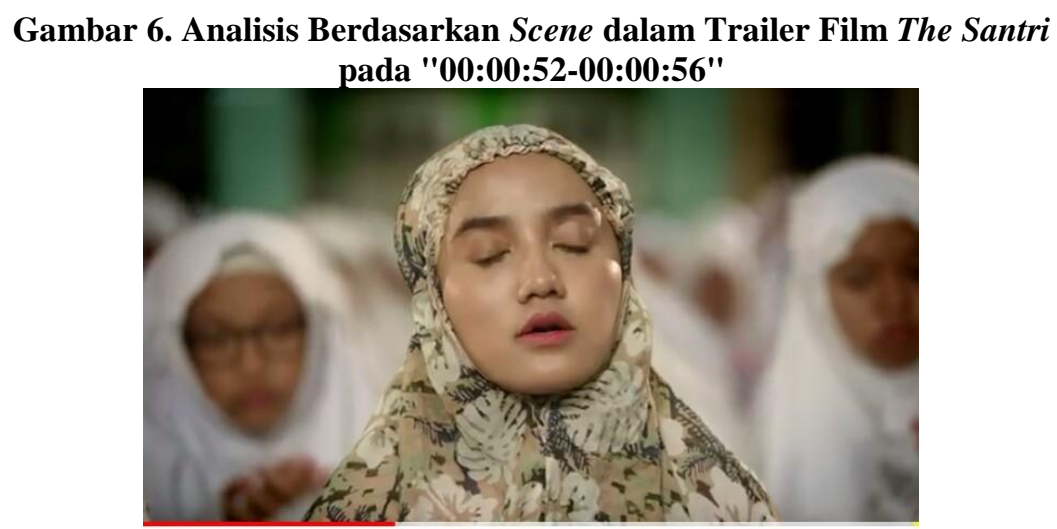

Sumber: Tangkapan Layar Trailer Film The Santri

Scene di atas menunjukkansignberupa berdoa. Klasifikasi tanda berdasarkan sign berjenis sinsign. Objeknya adalah seorang santri sedang berdoa agar mimpinya untuk dapat berkeliling dunia dikabulkan oleh Tuhan. Klasifikasi berdasarkan object berjenis indeks. Sedangkan interpretant dariscene ini menunjukkan bagaimana santri berdoa kepada Tuhan agarimpiannya terkabulkan. Artinya, santri selalu ingat dan memohon pertolongan kepada Tuhan. Klasifikasi berdasarkan interpretant berjenis dicint.

Peneliti menyimpulkan makna dari scene ini adalah santrimemiliki impian yang tinggi dan untuk mewujudkannya, selain berusaha santri juga berdoa. Dipilihnya Amerika bukan negara Timur Tengah lainnya, peneliti tafsirkan sebagai bentuk impian santri yang tidak terbatas yang ingin ditampilkan oleh film The Santri. Object berdasarkan jenis indeks, artinya adanya hubungan kausalitas. Berdoa merupakan indeks dari ketaatan kepada Tuhan. Scene ini merepresentasikan santri yang taat beribadah.

\section{Simpulan}

Berdasarkan hasil analisa dengan menggunakan model Charles Sanders Peirce tentang representasi santri dalam trailer film The Santri, peneliti dapat menyimpulkan beberapa hal sebagai berikut:

Ada beberapa representasi santri yang menuai kontroversi dalam trailer film tersebut. Di antaranya adalah scene yang menampilkan dua orang santriwati membawa tumpeng ke dalam 
gereja sebagai representasi dari toleransi antar agama, scene yang menampilkan seorang santriwan dan seorang santriwati menyusuri taman atau hutan sebagai representasi dari hubungan pertemanan antara laki-laki dan perempuan, dan scene yang menampilkan santriwan dan santriwati saling melirik satu sama lain sebagai representasi dari kedekatan hubungan antara laki-laki dan perempuan.

Beberapa scene yang peneliti maksudkan, memungkinkan penonton menafsirkannya sebagai representasi santri yang kurang ideal. Terdapatscene yang bersentuhan dengan legisign atau kaidah hukum. Seperti misalnya boleh tidaknya muslim masuk rumah ibadah agama lain. Di tengah masyarakat muslim, persoalan ini dipandang dengan berbeda-beda. Sehingga ketika trailer film The Santri ini dirilis dengan menampilkan scene tersebut, menjadi hal wajar apabila menimbulkan banyak pro dan kontra. Hal ini karena perbedaan pandangan di kalangan umat Islam itu sendiri.Termasuk juga scene yang menampilkan hubungan yang dekat antara seorang santriwan dan santriwati. Meskipun demikian, terdapat pula scene yang menampilkan kehidupan santri yang dipenuhi dengan mimpi, ibadah, dan persahabatan. Santri direpresentasikan sebagai generasi muda yang berani bermimpi tinggi dan berusaha untuk mewujudkannya, serta rajin beribadah.

Adanya banyak perbedaan pendapat di kalangan umat Islam memungkinkan representasi santri yang ditampilkan dalam trailer film ini menuai pro dan kontra. Namun demikian, peneliti menganggap hal itu sebagai sebuah kewajaran, karena media bukanlah clear window on the real. Media tidak dapat menampilkan semua pandangan tentang bagaimana santri seharusnya.Melainkan hanya sebagian sebagai hasil konstruksi dari pemilik media, dalam hal ini konstruksi santri ditentukan oleh NU sebagai penggagas lahirnya trailer film The Santri. 


\section{DAFTAR PUSTAKA}

Abdurrahman. 2017. "Sumbangan Pemikiran Nahdlatul Ulama (NU) Terhadap Modernisasi Pendidikan Islam Di Indonesia." Consilium IV(4).

Abu Yasid, Nahe'i, dkk. 2018. Paradigma Baru Pesantren: Menuju Pendidikan Islam Transformatif. Yogyakarta: IRCiSoD.

Ahmed, Saifuddin, and Jörg Matthes. 2017. "Media Representation Of Muslims And Islam From 2000 To 2015: A Meta-Analysis." International Communication Gazette 79(3): 219-44.

Alawi, Abdullah. "PBNU Melalui NU Channel Siap Luncurkan Film 'The Santri."” https://www.nu.or.id/post/read/110759/pbnumelalui-nu-channel-siap-luncurkan-film--the-santri- (June 7, 2020).

Alex Sobur. 2009. Semiotika Komunikasi. Bandung: PT Remaja Rosda Karya.

Bensoff, Griffin. 2004. America on Film: Representing Race, Class, Gender and Sexuality at the Movies. Victoria: Blackwell Publishing.

Binhad Nurrohmat. "Pesantren, NU, Indonesia." https://www.nu.or.id/post/read/85716/pesantren-nu-indonesia (June 7, 2020).

Branston, Gill, and Roy Stafford. 2010. The Media Student's Book, Fifth Edition. USA: Rotledge.

CNN. "Anggap Tak Sesuai Syariat, FUI Kecam 2 Adegan Film The Santri."

https://www.cnnindonesia.com/nasional/20190923085017-20432856/anggap-tak-sesuai-syariat-fui-kecam-2-adegan-film-thesantri (June 7, 2020a).

_. "Menantu Rizieq Shihab Kecam Film The Santri Karya Livi Zheng."

https://www.cnnindonesia.com/nasional/20190915160600-20430653/menantu-rizieq-shihab-kecam-film-the-santri-karya-livizheng? (June 7, 2020b).

CNN Indonesia. "Film The Santri Disebut Belum Diproduksi, Baru Trailer." https://www.cnnindonesia.com/nasional/20190918082035-20431440/film-the-santri-disebut-belum-diproduksi-baru-trailer 
(June 7, 2020).

Dadan Rusmana. 2014. Filsafat Semiotika Paradigma, Teori, Dan Metode Interpretasi Tanda Dari Semiotika Struktural Hingga Dekonstruksi Praktis. Bandung: CV Pustaka Setia.

Detik. "Rilis Trailer Lebih Dulu, 'The Santri' Baru Akan Mulai Syuting." https://hot.detik.com/movie/d-4710761/rilis-trailerlebih-dulu-the-santri-baru-akan-mulai-syuting (June 7, 2020).

Dewi, Murti Candra. 2013. "Representasi Pakaian Muslimah Dalam Iklan (Analisis Semiotika Charles Sanders Peirce Pada Iklan Kosmetik Wardah Di Tabloid Nova)." Profetik 6(2): 64.

Ditha Prasanti, Preciosa Alnahsava J. 2016. "Representasi Perempuan Dalam Iklan 'Fair and Lovely' Versi Nikah Atau S2." Ilmu Politik dan Komunikasi VI(1).

Hall, Stuart. 1997. "The Word of Representasion." Representation: Cultural Representations and Signifying Practices: 15-71.

Horvath, Adam, and Balazs Gyenge. 2018. "Movie Trailer Types And Their Effects On Consumer Expectations." International Journal of Business and Management Invention (IJBMI) 7(1): 94-99.

Marom, Ahmad Anfasul. 2012. "Kyai, Nu Dan Pesantren: Dalam Perspektif Demokrasi Deliberatif." Jurnal Agama dan Hak Azazi Manusia 2(1): 16-40.

Nurhadi, Zikri Fachrul. 2017. Teori Komunikasi Kontemporer. Penerbit Kencana.

Octavia, Lanny. 2014. Kumpulan Bahan Ajar Pendidikan Karakter Berbasis Tradisi Pesantren. Jakarta: Rumah Kitab.

Republika. "The Santri Bawa Pesan Kebhinekaan Dalam Islam Republika Online." https://www.republika.co.id/berita/senggang/film/19/09/10/pxl6 e6414-the-santri-bawa-pesan-kebhinekaan-dalam-islam (June 7, 2020).

Soebazary, Ilham. 2010. Kamus Istilah Televisi \& Film. Jakarta: PT Gramedia Pustaka.

Tribunnews. "Kontroversi Film The Santri: Alasan PBNU Gandeng Livi Zheng Hingga Reaksi Yusuf Mansur Dan Putrinya Tribunnews.Com."

https://www.tribunnews.com/seleb/2019/09/19/kontroversi-filmthe-santri-alasan-pbnu-gandeng-livi-zheng-hingga-reaksi-yusufmansur-dan-putrinya (June 7, 2020). 
Wibowo, Indiwan Seto Wahyu. 2013. Semiotika Komunikasi. Jakarta: Mitra Wacana Media.

Wikipedia. "Trailer (Promosi Film) - Wikipedia Bahasa Indonesia, Ensiklopedia Bebas." https://id.wikipedia.org/wiki/Trailer_(promosi_film) (June 7, 2020).

Zaini Mochtarom. 1988. Santri Dan Abangan Di Jawa. Jakarta: INIS. 